\title{
Obituaries
}

\section{Huibert Drion}

Dutch Supreme Court judge who became a leading advocate of euthanasia

"It appears to me ... that many old people would find great reassurance if they could have a means to end their lives in an acceptable way at the moment that to them . . appears suitable." It was with these words that Huib Drion, then a 74 year old former Supreme Court judge and professor of civil law, entered Dutch social history and became internationally renowned as a supporter of individual rights to suicide. Drion gave voice to a thread of Dutch opinion and sparked a debate that has outlived his death in his sleep at home in Leiden, apparently of natural causes, aged 86 on 20 April.

A learned lawyer, Drion was moved to write, almost as an intellectual exercise, after an elderly family member expressed concern at the prospect of ending her days in a nursing home. His article, "The self-chosen end for old people," appeared in the Dutch national newspaper NRC Handelsblad in 1991. He argued that people aged 75 or over, living alone, should have the choice of being provided by a doctor with the means to end their lives at a time and manner that was acceptable to them. This, he felt, would offer older people the knowledge that they could choose to die before experiencing the final stages of decline and dependence.

The autonomy from any real medical involvement set it starkly apart from the euthanasia debate then raging in the Netherlands, where a doctor's adherence to

\section{Advice}

We will be pleased to receive obituary notices of around 250 words. Pressure on space means that in most cases we will be able to publish only about 100 words in the printed journal, but we can run a fuller version on our website. We will take responsibility for shortening. We do not send proofs. Good quality, original photographs are welcome. Please give a contact telephone number and, where possible, supply the obituary on a disk or by email to obituaries@bmj.com

We need to know the year of birth and exact date of death of the deceased, and we prefer obituaries to state the cause of death. Please spell out abbreviations.

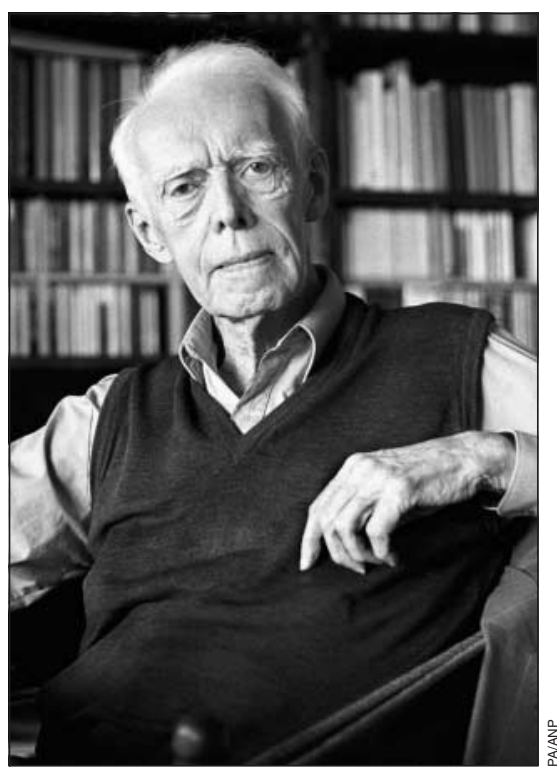

a range of requirements stood central. The Remmelink committee of inquiry into euthanasia that was to pave the way towards legislation published its findings in September 1991. Drion asked for his article to be held back so as to avoid confusion. He saw his proposal as a social rather than a medical one.

When his article appeared his ideas found fertile ground, being said to have put into words what many people were thinking. The NRC Handelsblad unusually published letters for several weeks. Drion received hundreds of letters, and requests for interviews and speaking engagements where, he is said to have commented mischievously, he could see mainly "lightgrey-haired elderly ladies."

While he was surprised by the intellectual debate that he had triggered, Drion also welcomed it. He never objected to the media coining the phrase "Drion's pill"-a concept rather than an actual suicide pill-and frequently gave interviews. But he avoided saying whether or not he would take advantage of it: "I do not know if I would use it, you know, because I am a coward."

$\mathrm{He}$ was not a coward, however. Even before writing his controversial editorial he had not been afraid to address dangerous subjects if he believed that they were right. Born in 1917, one of six children of a Dutch right wing liberal party MP, Drion studied law at Leiden University in 1938, when the Netherlands was split between supporters and opponents of national socialism. He led the Leiden Committee of Vigilance, a group of intellectuals opposing Nazi propaganda, and during the later occupation co-wrote a resistance newspaper with his brother Jan.

After the second world war an exemplary legal career saw him become professor of civil law at Leiden University and between 1981 and 1984 deputy president of the Supreme Court. However, it was as an incisive thinker concerned with social issues that he found notoriety.

His views have been durable, winning the support of former health minister Els Borst and shaping the new objectives of the Dutch Right to Die society (NVVL), of which he was a figurehead and honorary member since 1997.

Since euthanasia has been effectively decriminalised the NVVL has moved on to campaign for a "last will pill." NVVL chief executive officer Rob Jonquière said many members saw the self determination in Drion's ideas as the core of the issue. "People want the right to choose to end their life independent of doctors or illness."

Drion's views go far beyond the boundaries, set by today's euthanasia law and promoted by the Royal Dutch Medical Association (KNMG). However, Professor Johan Legemaate, the association's coordinator of legal policy, said that many doctors felt "some sympathy" for Drion's views, not least because he chose not to lay the burden on doctors' shoulders.

A study last year found that $25 \%$ of doctors supported the view that older people should be provided with the means to end their lives at a moment of their choice; $56 \%$ opposed it. [ToNy SHeldon]

Huibert Drion, former Dutch supreme court judge and professor of civil law Leiden University, the Netherlands (b 1917), d 20 April 2004. 


\section{Margaret Elizabeth Barden}

Former senior clinical medical officer in family planning Edinburgh (b 1935; q Bristol 1960; MFFP), died from cancer on 4 May 2003.

Elizabeth Barden worked in Kenya before moving to Scotland, where she trained in child health and family planning. Her main clinical role was in the family planning services in Lothian, where she developed new services and methods of contraception in the clinics and was a dedicated teacher of doctors in training. She was a medical officer for 19 schools in East Lothian and wrote a regular medical column for the Scotsman newspaper. Predeceased by her only son, she leaves two grandsons. [AILsA E Gebbie]

\section{Edward Granville Woodchurch Clarke}

Former general practitioner Binfield, Berkshire (b 1914; q Oxford/St Thomas's Hospital, London, 1940;MC), died from ischaemic vascular disease on 30 April 2003.

During the second world war he served in Burma, where he was awarded the Military Cross for bravery, rescuing casualties under fire. Returning from the war, he settled in Ruthin, Denbighshire, where he built up a thriving singlehanded practice. After 10 years he moved to Binfield in Berkshire, where he once again built up a singlehanded practice in the village. He enjoyed 20 years of retired life until Parkinson's disease affected his mobility. Predeceased by his wife, Patricia, he leaves three daughters and eight grandchildren. [CAROL FRENCH]

\section{Jeffrey Robert Clyne}

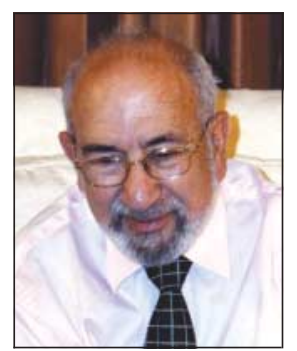

Former general practitioner Salford and director of occupational medicine Manchester Airport (b Manchester 1930; q Manchester 1954; MBE, JP,FRCGP), d 14 February 2004.

After his military service Jeffrey joined a general practice in Salford in 1957. He was involved in the diabetes clinic at Salford Royal Hospital and played a part in its research. Following retirement from general practice in 1987 Jeffrey developed an interest in occupational medicine, eventually being appointed director of occupational medicine at Manchester Airport. His interests included music, travelling abroad, and the appreciation of fine wines. $\mathrm{He}$ leaves a wife, Pearl; five children; and 10 grandchildren. [J Miles Walker]

\section{John Rodney Cove-Smith}

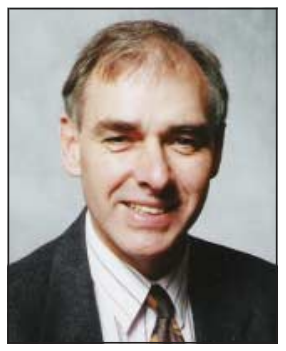

Consultant physician and nephrologist the James Cook University Hospital, Middlesbrough (b London 1943; $q$ Cambridge/St Thomas's Hospital, London, 1968; MD, FRCP, FRCP Ed), died from metastatic prostate cancer on 3 February 2004.

After junior posts in London and Dorset, Rod became senior registrar in renal medicine at Nottingham City Hospital, where he carried out research into analgesic nephropathy. He was appointed consultant in Middlesbrough in 1978. The James Cook University Hospital (JCUH) was then being built and Rod joined its commissioning team. He became chief of medicine and then associate medical director. He helped develop undergraduate medical training on Teesside and became honorary professor at Durham University in 2002. He headed the academic division at JCUH and saw completion of the academic centre and its library, named after him, a few weeks before he died. He leaves a wife, Jackie; three daughters; and a grandson. [Jackie Cove-Smith]

\section{Frances Mary Fountain}

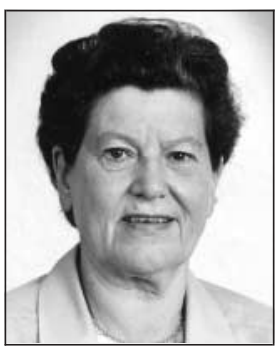

Former consultant obstetrician and gynaecologist Harrogate and Ripon Hospitals Group (b Knaresborough 1922;

$q$ Cambridge/Manchester 1946; FRCOG), died on 9 December 2003 after a series of strokes. Frances's progression to consultant was interrupted by health problems and family worries, and so she entered general practice for some years. She was appointed consultant to the Harrogate group of hospitals in 1973, thus joining the unbroken line of female obstetricians stretching from the early years of the last century that has given Harrogate mothers the choice of a woman consultant for their deliveries. Frances had a Cambridge blue for cricket and took delight in watching football, tennis, horseracing, and golf, taking up golf herself in retirement. She was also an excellent hostess. [SHEILA Moore]

\section{George Douglas McIntosh}

Former general practitioner Inverness (b Edinburgh 1914; q Edinburgh 1937;MC), died from cardiac failure on 28 February 2004. As a reservist he was called up shortly before the second world war and was in France by the end of September 1939. He took part in the retreat to Dunkirk, where he was wounded and was awarded the Military Cross. On recovery he was posted to Northern Ireland, and then to north Africa and Italy. After demobilisation he took up practice in Arisaig. In 1952 he was appointed to a practice in Inverness and later joined a group practice until he retired in 1981. He leaves a wife, Mary; two daughters; and three grandchildren. [A D McINTOSH]

\section{James Willocks}

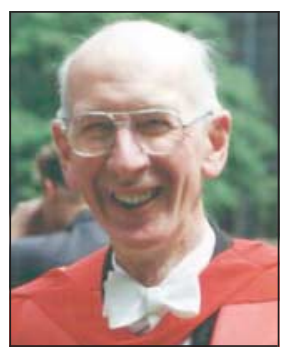

Former consultant obstetrician Glasgow (b Lanarkshire 1928; q Glasgow 1951; MD, FRCOG, FRCP Glas), died from motor neurone disease on 13 February 2004.

James Willocks was a leading figure in British obstetrics for 30 years. His particular contribution was in ultrasound scanning of the fetal head to assess size and growth of the fetus (ultrasonic cephalometry), a technique that was for years the only method of monitoring intrauterine fetal growth. After house jobs he saw active service in the Far East. His training in obstetrics and gynaecology began at Glasgow Royal Maternity Hospital. He moved as lecturer in midwifery to the Queen Mother's Hospital (QMH) in Glasgow, when it opened in 1964. In 1966 he was appointed NHS consultant to the $\mathrm{QMH}$ and Glasgow Western Infirmary, where he remained until his retirement in 1990. His textbook Essentials of Obstetrics and Gynaecology ran to five editions. He leaves a wife, Elma, and three daughters. [L J Willocks, A W F Miller]

Longer versions of these obituaries are available on bmj.com 